\title{
食品製造副産物を主原料とした肥育豚用 発酵リキッド飼料の調製と給与成績
}

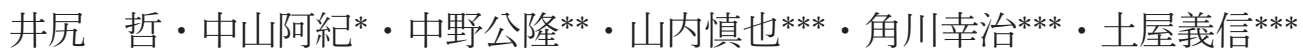

食協株式会社，広島市南区松川町 5-9，732-0826

* 株式会社カンサイ，広島市佐伯区五日市町大字石内 460, 731-5127

**広島県立西条農業高等学校，東広島市鏡山 3-16-1，739-0046

*** 広島県立総合技術研究所食品工業技術センター，広島市南区比治山本町 12-70， 732-0816

（2006 年 6 月 13 日受付， 2006 年 11 月 29 日受理）

要 約 まだ十分に有効利用されていない広島県内の食品工場製造副産物の飼料化を推 進するため，発酵リキッド法による肥育豚用飼料への活用を検討した。

食品製造副産物である食パン耳, 馬鈴薯皮, ポテトチップ屑, ジャム製品ロス, 緑茶抽 出かす，および豆腐かすを主原料とし，これに養分調整のために数種類の飼料原料を混合 して, 肥育豚の栄養要求量を満たす飼料設計を行った発酵りキッド飼料（FLF）を調製し た。

原料 $105 \mathrm{~kg}$ を粉砕, 混合し, 加熱殺菌した後, 冷却し, スターターとして Lactobacillus

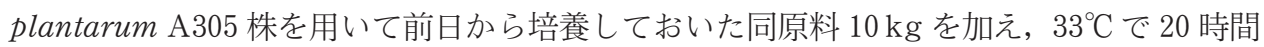
培養した。培養後の FLF は $10^{9.4}$ 個/ g という高濃度の乳酸菌を含み, $\mathrm{pH}$ は 4.2 を示した。 乾燥配合飼料（FF）と調製した FLF を肥育豚に給与し，発育掞よび飼料の利用性に及 ぼす影響を調べた。試験には 99 日齢の肥育豚 11 頭を用い，体重を揃えて，対照区と試験 区に割り付け，対照区にはFFを，試験区にはFLFをそれぞれ 20 日間不断給餌した。

その結果，4 日間の FLF 馴致期間を除く 16 日間の発育成績を比較すると， 1 日平均増 体量 (DG) は，対照区および試験区それぞれ $965 \mathrm{~g}, 1,207 \mathrm{~g}$ となり, 試験区の方が対照区よ りあ有意 $(\mathrm{p}<0.05)$ に高かった。

1 日当たり飼料摂取量は, 試験区が $14,271 \mathrm{~g}$ （乾物換算 : $3,568 \mathrm{~g}$ ), 対照区が $3,750 \mathrm{~g}$ （乾 物換算: $3,048 \mathrm{~g}$ ) であった。乾物摂取量での飼料要求率は, 試験区 2.96 , 対照区 3.16 で試 験区は対照区に比べて飼料効率が約 $6 \%$ 優れていた。

以上の結果から，広島県内において，現在，食パン耳以外はコンポスト原料とされてい

Preparation of Fermented Liquid Feed Using By-products of Food Processing and the Growth Performance in Pigs

S. IJiRI, A. NAKAYAma*, K. NAKAnO**, S. Yamauchi***, K. KAKUGAWA ${ }^{* * *}$ and Y. TsuchiYa ${ }^{* * *}$ Shokkyo Co., Ltd., 5-9 Matsukawa-chou, Minami-ku, Hiroshima-shi, Hiroshima 732-0826, Japan

* Kansai Co., Ltd., 460 Ishiuchi, Itsukaichi-chou, Saeki-ku, Hiroshima-shi, Hiroshima 7315127, Japan

** Hiroshima Prefectural Saijo Agricultural High School, 3-16-1 Kagamiyama, Higashihiroshima-shi, Hiroshima 739-0046, Japan

*** Hiroshima Prefectural Technology Research Institute Food Technology Research Center, 12-70 Hijiyamahon-machi, Minami-ku, Hiroshima-shi, Hiroshima 732-0816, Japan 連絡者:井尻 哲 (E-mail : ijiri@shokkyo.co.jp Tel. 082-264-1311) 
るこれらの製造副産物は，発酵リキッド化法により飼料利用できることが実証され，資源 の有効活用と排出サイド・畜産サイド双方の経済性向上に寄与できる可能性が示唆され た。

\section{緒言}

飼料自給率の向上と飼料費の低減を図るため, 「新たな食料・農業・農村基本計画 ${ }^{1} 」$ では，「食 品循環資源の再生利用等の促進に関する法律」 （食品リサイクル法）に準拠して, 食品残さの飼料 化を推進することを明記しており, 近年, 全国各 地で活発な取り組みが行われている2。

食品残さは, 古くから主に養豚飼料として利用 されてきたが, 質・量の不安定, 腐敗, 異物混入 等の問題, また, 不飽和脂肪酸の多い脂質の多量 摂取による軟脂豚の発生, 残飯加熱時の悪臭発生 等により敬遠され, 昭和 40 年代以降, この有用資 源の循環利用は激減した ${ }^{3)}$ 。

しかし, 阿部らの精力的な普及活動 ${ }^{4)}$, 川島, 佐 伯による栄養面の検討 ${ }^{5}$, 入江らによる肉質改善 研究6), 淡路による経済性検討7) などの研究と, 国 が強力に推進する「バイオマスニッポン総合戦 略 ${ }^{8)} 」$ を背景に, 全国各地で食品残さ飼料利用の 新たな展開が急速に広がっている。

食品残さを飼料化する方法として, 乾燥法, サ イレージ化法, リキッド飼料化法などが報告され ている2)。

リキッド飼料化法は, かつて, 腐敗や配管内一 の詰まり等, 給慨面でのトラブルが普及の妨げと なっていたが, 北欧での実践的研究, とりわけ, 乳酸菌等を利用した発酵リキッド飼料（FLF）の 有害微生物抑制作用やプロバイオティックス効 果 ${ }^{9)}$ が注目されている。

著者らは, この方法に着目して, 未だ十分に利 活用されていない広島県内の食品工場で発生して いる食品製造副産物 ${ }^{10)}$ (産業廃棄物: 動植物性残 さに区分される）を発酵リキッド化法により飼料 化利用することを共同で研究しており, 乳酸発酵 方法の検討, 試作 FLF の品質や保存性, 摂取し た豚の発育成績, 腸内菌叢変化 (別報) 等を検証 するため一連の研究に取り組んできた。
本報告では FLF の調製方法と給与成績につい て報告する。

\section{材料および方法}

\section{FLF の調製}

（1）供試食品製造副産物

本研究に参加した食品メーカー他の製造ライン より排出する食パン耳, 馬鈴薯皮, ポテトチップ 屑, ジャム製品口ス, 緑茶抽出加, 豆腐かすの 6 種類の製造副産物を主原料とし, 供試豚の栄養 要求量を満たすため, 大豆かすミール, $65 \%$ 調整 魚粉, 第 3 リン酸カルシウム, 豚用総合サプリメ ントの 4 種類の飼料原料を用いて成分調整を行な いFLF を調製した。これらの栄養成分を飼料の 公定規格 ${ }^{11)}$ に準じて分析した。（表 1）

\section{(2) 供試乳酸菌}

本研究では, 前報 ${ }^{12)}$ で報告した, 高いデンプン 資化性と胃酸, 胆汁耐性を有する乳酸菌 Lactobacillus plantarum A305株をスターターとして用 いた。

（3）スターターの調製

プレスターターは, 精米工場の無洗米製造工程 より排出する高濃度洗米排水をべースにした培地 を使用し，前報 ${ }^{12)}$ に記載した方法で， $33^{\circ} \mathrm{C}, 24$ 時 間培養した。

スターターは当日仕込んだ加熱殺菌直後の原料 を, 無菌的にステンレス容器に $10 \mathrm{~kg}$ 分取し, こ れに滅菌水 $2 \mathrm{~kg}$ を加え, 品温が $35^{\circ} \mathrm{C}$ 以下に低下 するのを待って，プレスターター $1 \mathrm{~kg}$ を加え， $30^{\circ} \mathrm{C}$ で 24 時間培養した。

(4) FLF の調製

飼料の調製フローを図 1 に示した。

表 2 に示した投入原料 $105 \mathrm{~kg}$ が, $100^{\circ} \mathrm{C} \cdot 30$ 分 間の殺菌, 冷却後, 水分蒸散により約 $90 \mathrm{~kg}$ に減 量した。これに同原料で前日より調製したスター ター $10 \mathrm{~kg}$ を加えて, $33 \pm 3^{\circ} \mathrm{C}$ で約 20 時間培養 し，FLF を調製した。発酵後の製品収量は約 90 
表 1. 原料として用いた食品製造副産物と成分分析值

Table 1. List of food processing by-products for FLF and their chemical composition

\begin{tabular}{|c|c|c|c|c|c|c|c|c|}
\hline & & $\begin{array}{c}\text { 食パン } \\
\text { 耳 }\end{array}$ & $\begin{array}{c}\text { 馬鈴薯 } \\
\text { 皮 }\end{array}$ & $\begin{array}{l}\text { ポテト } \\
\text { チップ } \\
\text { 屑 }\end{array}$ & $\begin{array}{l}\text { ジャム } \\
\text { 製品 } \\
\text { ロス }\end{array}$ & $\begin{array}{l}\text { 緑茶 } \\
\text { 抽出 } \\
\text { 加す }\end{array}$ & 豆腐 & 試験方法 \\
\hline 水分 & $\%$ & 31.32 & 83.74 & 4.72 & 52.19 & 78.12 & 77.91 & 熱風乾燥法 \\
\hline 粗蛋白質 & " & 5.98 & 0.30 & 0.20 & 0.52 & 2.99 & 4.91 & ケルダール法 \\
\hline 粗脂肪 & " & 2.60 & 1.26 & 28.50 & 0.06 & 1.01 & 2.85 & ソックスレー法 \\
\hline 粗繊維 & "1 & 0.03 & 2.83 & 0.47 & 0.40 & 4.26 & 2.93 & ファイバーテック法 \\
\hline 粗灰分 & " & 2.38 & 4.27 & 3.58 & 0.51 & 3.13 & 4.07 & 強熱残量 \\
\hline 可溶性無窒素物 & " & 57.69 & 7.60 & 62.53 & 46.32 & 10.49 & 7.33 & 計算による \\
\hline $\mathrm{ADF}$ & " & 1.35 & 6.51 & 15.76 & 0.55 & 6.98 & 4.93 & Vansoest 法 \\
\hline $\mathrm{NDF}$ & " & 1.41 & 6.91 & 15.77 & 0.57 & 7.35 & 5.60 & Vansoest 法 \\
\hline カルシウム & $\mathrm{mg} / 100 \mathrm{~g}$ & 48 & 39 & 22 & 11 & 110 & 61 & ICP 法 \\
\hline リン & " & 48 & 9 & 110 & 7 & 21 & 30 & 吸光光度法 \\
\hline ナトリウム & " & 390 & 81 & 22 & 5 & 16 & 2 & 原子吸光光度法 \\
\hline カリウム & " & 170 & 110 & 1700 & 41 & 120 & 350 & 原子吸光光度法 \\
\hline マグネシウム & " & 32 & 16 & 73 & 6 & 33 & 31 & ICP 法 \\
\hline 食塩（Na 換算） & " & 990 & 210 & 57 & 12 & 41 & 5 & 日本食品標準成分表 \\
\hline 熱量 & $\mathrm{kcal} / \mathrm{kg}$ & 2930 & 500 & 4650 & 1510 & 880 & 860 & ボンブ法 \\
\hline
\end{tabular}

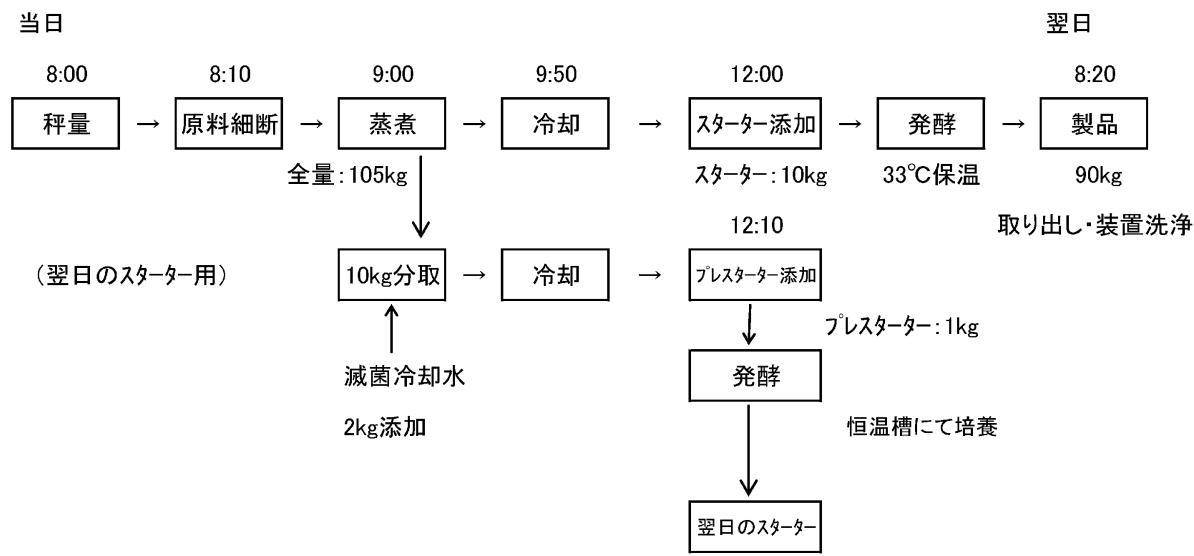

図 1. 発酵リキッド飼料（FLF）の調製方法

Fig. 1. Method for preparation of the FLF in this experiment

$\mathrm{kg}$ であった。発酵後のスターター, 発酵前の加熱 冷却後原料, 20 時間発酵後の FLF, およびこの調 製品 $10 \mathrm{~kg}$ をポリ袋に入れ, 実験室内（室温）で 24 時間保存後の乳酸菌数, 酵母数, $\mathrm{pH}$, ないし乳 酸量を測定した。また, 乳酸発酵によって飼料成
分がどのように変化するかを調べるため, 加熱直 後 (スターター添加前) の原料之, スターターを 添加して 20 時間発酵させた FLF $10 \mathrm{~kg}$ をポリ袋 に入れ, 実験室内 (室温) で 48 時間保存したもの について, 一般成分, アミノ酸組成, 脂肪酸組成 
表 2. FLF の原料配合割合之養分設計值, 成分分析値

Table 2. Ingredients of FLF and its chemical composition

\begin{tabular}{|c|c|c|c|c|c|}
\hline 飼料原料 & $(\%)$ & 養分 & & 設計值 & 分析值 ${ }^{1}$ \\
\hline 食パン耳 & 13.32 & 乾物量 & $(\%)$ & 25.0 & 25.0 \\
\hline 馬鈴薯皮 & 4.76 & 粗蛋白質 & $(\%)$ & 4.8 & 3.8 \\
\hline ポテトチップ屑 & 4.76 & 可消化エネルギー & $(\mathrm{kcal} / \mathrm{kg})$ & 1070.0 & - \\
\hline ジャム製品ロス & 3.81 & 可消化養分総量 & $(\%)$ & 24.3 & - \\
\hline 緑茶抽出かす & 1.90 & カルシウム & $(\%)$ & 0.24 & 0.89 \\
\hline 豆腐かす & 2.85 & リン & $(\%)$ & 0.17 & 0.59 \\
\hline 大豆かすミール & 2.85 & リジン & $(\%)$ & 0.23 & 0.21 \\
\hline $65 \%$ 調整魚粉 & 1.43 & \multirow{5}{*}{\multicolumn{4}{|c|}{ 1) 調製した FLF 原物中 \% (2 点の平均値). }} \\
\hline 第 3 リン酸カルシウム & 0.38 & & & & \\
\hline 豚用総合サプリメント & 0.17 & & & & \\
\hline 水 & 63.77 & & & & \\
\hline 合計 & 100.00 & & & & \\
\hline
\end{tabular}

を測定した。

\section{(5) 飼料の栄養設計}

日本飼養標準 $\left(\right.$ 豚 $\left.{ }^{13}\right)$ に示されている体重 $30 \mathrm{~kg}$ 〜 70 kg の豚の養分要求量に従って, 供試豚の体 重を $60 \mathrm{~kg}$ ，期待増体日量を $1,000 \mathrm{~g}$ として，FLF の養分水準を設計し, 製造副産物と飼料原料の配 合割合を決定した。

表 2 に各原料の配合割合, 養分設計值, および 成分分析值を示した。

（6）対照飼料

対照区には，市販の子豚育成用配合飼料（CP : 16.0\%，TDN : 77\%）を不断給餌した。供試した 配合飼料 (FF) 表示成分值, および成分分析結果 を表 3 に示した。

\section{2. 豚への給与試験}

(1) 試験期間

2005 年 1 月 13 日〜 2 月 2 日の 20 日間, 飼育試 験を実施した。

(2) 供試豚

広島県立西条農業高等学校実習農場養豚舎で飼 育されている 2004 年 10 月 6 日生の大ヨーク シャー種同腹豚 11 頭 (99 日齢) を供試し, 対照区 には 5 頭（去勢雄 3, 雌 2), 試験区には 6 頭（去 勢雄 4, 雌 2）を割り付けた。各区の平均体重は, 対照区 $58.7 \mathrm{~kg}$, 試験区 $60.2 \mathrm{~kg}$ であった。これら
表 3. 対照区に与えた FF の表示成分値, 成分分析值

Table 3. Chemical composition of FF for control pigs

\begin{tabular}{|c|c|c|c|}
\hline & & 表示成分値 & 分析値 \\
\hline 水分 & $\%$ & & 18.71 \\
\hline 粗蛋白質 & " & 16.0 以上 & 19.71 \\
\hline 粗脂肪 & "1 & 3.0 以上 & 4.25 \\
\hline 粗繊維 & " & 5.0 以下 & 2.06 \\
\hline 粗灰分 & "1 & 8.0 以下 & 4.74 \\
\hline 可溶性無窒素物 & " & & 50.53 \\
\hline $\mathrm{ADF}$ & " & & 5.86 \\
\hline $\mathrm{NDF}$ & "1 & & 6.36 \\
\hline カルシウム & $\mathrm{mg} / 100 \mathrm{~g}$ & 500 以上 & 790 \\
\hline リン & 11 & 400 以上 & 860 \\
\hline ナトリウム & " & & 160 \\
\hline カリウム & " & & 890 \\
\hline マグネシウム & " & & 180 \\
\hline 食塩（Na 換算） & " & & 410 \\
\hline 熱量（GE） & $\mathrm{kcal} / \mathrm{kg}$ & & 2800 \\
\hline 可消化養分総量 & $\%$ & 77.0 以上 & \\
\hline
\end{tabular}

を各々間口 $1.8 \mathrm{~m} \times$ 奥行き $4.8 \mathrm{~m}$ （うち $3.6 \mathrm{~m}$ はコ ンクリート床， $1.2 \mathrm{~m}$ は木製スノコ床）の豚房に 
群飼し，ニップル給水器により自由飲水させた。

(3) 給与方法

対照区には 6 頭口のセルフフィーダーを使用 し，不断給慨した。

試験区は, 開始時の飼料の切り替えを段階的に 行うこととし，それまで与えていた対照区と同様 の FF を開始当日は半量混ぜ, 翌日から徐々に減 らして 5 日目から 100\% FLFに切り替えた。5 頭 口のリキッド給餌器を豚房に固定し，5 日目以降 は, 午前 8 時, 正午, 及び午後 5 時の 3 回, 各 30 $\mathrm{kg}$ ずつ合計 $90 \mathrm{~kg}$ を上部に設けた投入口から流 し込んだ。翌朝 8 時の給餌の際, 給餌器に目測で $10 \mathrm{~kg}$ 以上の残飼があれば, 取り出して重量を測 定し, 給与量から減じて廃棄した。試験区の飼料 摂取量は開始時から 4 日目まで混ぜた FF の給与 量を加えた。

供試豚の 1 日増体量は, 飼料への馴致期間を含 めた 0 20 日の平均増体量と, 飼料への馴致が終 了した 4 20 日の平均増体量の両方を求め, 表 6 に示した。

\section{(4) 調査項目}

広島県立西条農業高等学校畜産科 2 学年養豚プ ロジェクトチーム 9 名の生徒が以下の項目につい て測定，記録，試料採取等を行った。

- 体重 (開始時, 1 週後, 2 週後, 3 週後)

・ 飼料摂取量（飼料給与量, 残飼量)

・豚の健康状態（粪便の状態, 被毛の状態)

・畜舎環境（温湿度，臭気，ほこり）

\section{結果および考察}

\section{1. 調製した FLF の品質}

(1) 設計值と調製後の栄養成分

日本標準飼料成分表（2001 年版 ${ }^{14)}$ に基づいて 栄養設計した飼料の養分設計值と, 実際に調製し たFLFの成分分析值を表 2 に示した。

乾物量は設計值と一致したが，粗蛋白質含量は 設計值よりも低い值を示した。これは本試験で使 用した各メーカーの製造副産物が，日本標準飼料 成分表に記載されているこれらの表示成分值より あ, 全体的に水分が高く, 粗蛋白質含量が低かっ たことによるものと考えられた。

（2）調製と保存に伴う微生物と乳酸の経時的变 化

スターター調製時，および飼料調製時における 乳酸菌数, 酵母数, $\mathrm{pH}$, 乳酸含量を表 4 に示した。 加熱殺菌後のスターター原料, および飼料原料か らは乳酸菌, 酵母は検出されなかった。プレス ターターまたはスターターを添加して 1 日発酵さ せた後では, 乳酸菌数は $10^{9}$ 個/g に増殖した。し かし, 酵母の増殖は認められなかった。プレス ターターまたはスターターを添加して発酵させる ことにより, 乳酸菌が増殖して乳酸を産生するた め, 発酵後, スターターまたはFLF の乳酸含量 は，それぞれ $11.4 \mathrm{~g} / \mathrm{L}, 11.5 \mathrm{~g} / \mathrm{L}$ となり, $\mathrm{pH}$ は 4.0，4.2 まで低下した。さらに，これを室温で 24 時間保存したものは, 乳酸量が $12.2 \mathrm{~g} / \mathrm{L}$ に達し, $\mathrm{pH}$ は 4.1 となった。また, 乳酸菌数は同水準で, 酵母の増殖は認められなかった。

表 4. スターターおよび FLF 調製時の微生物数と乳酸量

Table 4. Temporal changes of biological and chemical qualities by processing the starter and FLF

\begin{tabular}{clcccc}
\hline \hline 試 料 & \multicolumn{1}{c}{$\begin{array}{c}\text { 採材過程 } \\
\text { スターター }\end{array}$} & $\begin{array}{c}\text { 乳酸菌数 } \\
(\text { 個 } / g)\end{array}$ & $\begin{array}{c}\text { 酵母数 } \\
(\text { 個 } / g)\end{array}$ & $\mathrm{pH}$ & $\begin{array}{c}\text { 乳酸 } \\
(\mathrm{g} / \mathrm{L})\end{array}$ \\
\hline \multirow{3}{*}{$\mathrm{FLF}$} & 24 時間発酵後 & $2.1 \times 10^{9}$ & 200 以下 & 4.0 & 11.4 \\
& 原料加熱冷却後 & 300 以下 & 200 以下 & 6.3 & 0.0 \\
& 20 時間発酵後 & $2.4 \times 10^{9}$ & 200 以下 & 4.2 & 11.5 \\
& 室温 24 時間保存後 & $1.9 \times 10^{9}$ & 200 以下 & 4.1 & 12.2 \\
\hline
\end{tabular}


表 5. 発酵による飼料成分の変化

Table 5. Change of chemical composition of FLF by fermentation

\begin{tabular}{|c|c|c|c|}
\hline & & $\begin{array}{c}\text { 登酵前 } \\
\text { 加熱後原料 }\end{array}$ & $\begin{array}{c}\text { 発酵後 } \\
\text { 室温 } 48 \text { 時間保存後 }\end{array}$ \\
\hline \multicolumn{4}{|c|}{ 1. 一般成分, ミネラル, 熱量 } \\
\hline 水分 & $(\%)$ & 75.59 & 72.85 \\
\hline 粗蛋白質 & $(\%)$ & 5.31 & 5.44 \\
\hline 粗脂肪 & $(\%)$ & 2.61 & 1.85 \\
\hline 粗繊維 & $(\%)$ & 0.51 & 0.87 \\
\hline 粗灰分 & $(\%)$ & 5.65 & 5.70 \\
\hline 可溶性無窒素物 & $(\%)$ & 10.33 & 13.29 \\
\hline カルシウム & $(\mathrm{mg} / 100 \mathrm{~g})$ & 960 & 940 \\
\hline リン & $(\mathrm{mg} / 100 \mathrm{~g})$ & 720 & 610 \\
\hline ナトリウム & $(\mathrm{mg} / 100 \mathrm{~g})$ & 500 & 290 \\
\hline カリウム & $(\mathrm{mg} / 100 \mathrm{~g})$ & 830 & 450 \\
\hline マグネシウム & $(\mathrm{mg} / 100 \mathrm{~g})$ & 120 & 110 \\
\hline 食塩 & （Na 換算） & 1300 & 740 \\
\hline 熱量 & (kcal) & 660 & 720 \\
\hline \multicolumn{3}{|l|}{ 2. アミノ酸組成 ${ }^{1)}$} & $(\mathrm{mg} / 100 \mathrm{~g})$ \\
\hline \multicolumn{2}{|l|}{ 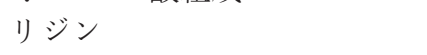 } & 200 & 210 \\
\hline \multicolumn{2}{|l|}{ メチオニン } & 100 & 79 \\
\hline \multicolumn{2}{|l|}{ シスチン } & 79 & 65 \\
\hline \multicolumn{2}{|l|}{ アスパラギン酸 } & 380 & 350 \\
\hline \multicolumn{2}{|l|}{ グルタミン酸 } & 960 & 910 \\
\hline \multicolumn{3}{|l|}{ 3. 脂肪酸組成 ${ }^{2)}$} & $(\%)$ \\
\hline \multicolumn{2}{|l|}{ C $12: 0$} & 0.8 & 0.9 \\
\hline \multicolumn{2}{|l|}{ C $14: 0$} & 0.9 & 1.1 \\
\hline \multicolumn{2}{|l|}{ C $14: 1$} & 0.0 & 0.0 \\
\hline \multicolumn{2}{|l|}{ C $16: 0$} & 22.4 & 24.4 \\
\hline \multicolumn{2}{|l|}{ C $16: 1$} & 0.4 & 0.1 \\
\hline \multicolumn{2}{|l|}{ C $18: 0$} & 3.5 & 3.4 \\
\hline \multicolumn{2}{|l|}{ C $18: 1$} & 35.0 & 36.0 \\
\hline \multicolumn{2}{|l|}{ C $18: 2 \quad n-6$} & 29.4 & 27.4 \\
\hline \multicolumn{2}{|l|}{ C $18: 3 \quad n-3$} & 4.5 & 3.8 \\
\hline \multicolumn{2}{|l|}{ C $18: 4 \quad n-3$} & 0.0 & 0.0 \\
\hline \multicolumn{2}{|l|}{ C $20: 0$} & 0.4 & 0.4 \\
\hline \multicolumn{2}{|l|}{ C $20: 1$} & 0.4 & 0.3 \\
\hline \multicolumn{2}{|l|}{ C $20: 2$} & 0.0 & 0.0 \\
\hline \multicolumn{2}{|l|}{ C $20: 3 \quad n-3$} & 0.1 & 0.1 \\
\hline \multicolumn{2}{|l|}{ C $20: 5 \quad n-3$} & 0.3 & 0.3 \\
\hline \multicolumn{2}{|l|}{ C $22: 0$} & 0.2 & 0.1 \\
\hline \multicolumn{2}{|l|}{ C $22: 1 \quad n-9$} & 0.1 & 0.1 \\
\hline \multicolumn{2}{|l|}{ C $24: 0$} & 0.2 & 0.1 \\
\hline \multicolumn{2}{|l|}{ C $18: 2 /$ C $18: 0$} & 24.9 & 22.2 \\
\hline
\end{tabular}

1) アミノ酸組成は, 「改訂 日本アミノ酸組成表」の方法による.

2)脂肪酸組成は，ガスクロマトグラフ法による。 
表 6 . 給与試験の発育成績

Table 6. Growth performance of pigs

\begin{tabular}{|c|c|c|c|c|}
\hline \multirow{3}{*}{$\begin{array}{l}\text { 供試頭数 } \\
\text { 試験期間 }\end{array}$} & & & 対照区 & 試験区 \\
\hline & & & \multirow{2}{*}{\multicolumn{2}{|c|}{$\begin{array}{c}\mathrm{n}=5 \text { (去勢雄 : } 3, \text { 雌 : } 2) \quad \mathrm{n}=6 \text { (去勢雄 : } 4 \text {, 雌 : } 2) \\
2005 \text { 年 } 1 \text { 月 } 13 \text { 日 } 2 \text { 月 } 2 \text { 日（20日間） }\end{array}$}} \\
\hline & & & & \\
\hline 試験開始時平均体重 & & $\mathrm{kg}$ & $58.7 \pm 10.1$ & $60.2 \pm 5.4$ \\
\hline 飼料馴致終了時体重 & (4 日後) & $\mathrm{kg}$ & $63.4 \pm 10.4$ & $65.7 \pm 6.3$ \\
\hline 試験終了時平均体重 & (20 日後) & $\mathrm{kg}$ & $78.8 \pm 12.0$ & $85 \pm 6.2$ \\
\hline 1 日平均増体量 & $(0 \sim 20$ 日) & $\mathrm{g}$ & $1008^{\mathrm{a}} \pm 180$ & $1243^{\mathrm{b}} \pm 106$ \\
\hline " & (4〜20 日) & $\mathrm{g}$ & $965^{\mathrm{a}} \pm 206$ & $1207^{\mathrm{b}} \pm 119$ \\
\hline 1 日平均摂取原物飼料量 & $(0 \sim 20$ 日) & $\mathrm{g}$ & 3800 & 13700 \\
\hline 11 & (4〜20 日) & $\mathrm{g}$ & 3750 & 14271 \\
\hline 1 日平均摂取乾物飼料量 & $(0 \sim 20$ 日) & $\mathrm{g}$ & 3089 & 3631 \\
\hline " & $(4 \sim 20$ 日) & $\mathrm{g}$ & 3048 & 3568 \\
\hline 乾物摂取量基準飼料要求量 & $(0 \sim 20$ 日) & & 3.06 & 2.92 \\
\hline "1 & (4〜20 日) & & 3.16 & 2.96 \\
\hline
\end{tabular}

$\mathrm{a}$ と $\mathrm{b}$ に有意差 $(\mathrm{P}<0.05)$ あり.

（3） 発酵による飼料成分の变化

発酵前および発酵後 48 時間室温保存した飼料 の成分変化を表 5 に示した。

加熱処理と発酵により, 水分と粗脂肪が減少 し, 可溶性無窒素物 (NFE) は増加する傾向が見 られた。また, 脂肪酸組成では, リノール酸（C18 : 2), リノレイン酸 (C18:3) が減少する傾向が見 られた。

\section{2. 給与豚の発育成績}

試験期間中の畜舎内平均気温は $7^{\circ} \mathrm{C}$, 湿度は 50 〜 80\%であった。表 6 に発育成績を示した。20日 間の試験期間のうち, 試験区に FLF を馴致させ るために FF を混合給与した期間を除いた 4 日目 〜最終日 (16 日間) について, 対照区は 1 日平均 $3,750 \mathrm{~g}$ （乾物換算 $3,048 \mathrm{~g}$ ）の FF を，試験区は 1 日平均 $14,271 \mathrm{~g}$ (乾物換算 $3,568 \mathrm{~g}$ ) の FLF を摂取 した。調製したFLF は強い酸味を示したが，試 験区の豚は優れた嗜好性を示した。増体成績もこ れを反映して, 試験区（1,207 g) は対照区（965 g) を $25 \%(\mathrm{P}<0.05)$ 上回る $\mathrm{DG}$ を示した。乾物摂取 量を基準にして飼料要求率を求めると, 対照区は 3.15 (100), 試験区は 2.96 (94) であり, 試験区が 優れていた。BROOKS ら ${ }^{15)}$ は飼料中の水分含量の
増加は, 豚の消化酵素による消化物のより効果的 な浸透を可能とし，同時に，消化管システムにお ける粘度と通過率を減少させて, 乾物消化率と可 消化エネルギーを改善すると報告しているが，今 回の試験においても, FLF の飼料要求率は乾物 飼料の FF よりも優れていた。ただし，本試験は 供試飼料の給与期間が 20 日間と短いため, 追試 による検証が必要と考える。

20 日間を通算した発育成績でも, 試験区は対照 区を上回る増体成績を示し, 飼料要求率も優れて いた。

両区の糞便性状は大きく異なり, 対照区は黄褐 色で未消化物が混在したが, 試験区の便は黒色で 粘性が強く, 未消化物はなかった。また, 試験期 間を通じて, 軟便や下痢はなく, 両区とも被毛の 状態, 健康状態は良好であった。畜舎内のほこり や臭気に関しては，両区とも「不快臭，ほこりが ほとんどない」と記録されていて，区間に差は認 められなかった。

本試験に先立ち, FLF の調製方法や嗜好性を 検討する目的で, 2004 年 11 月 4 日〜 11月 24 日 の 20 日間, 予備試験を実施して, それまで給与し ていた乾物配合飼料から FLFに切り替えた後の 
数日間は摂取量が大きく低下するが，それ以降は FLF に馴致して, 給与した全量を数時間以内に 完食するほどの優れた嗜好性と増体成績, 飼料効 率を確認したが, 本試験においても, 予備試験と ほぼ同様の知見を得た。

本研究では, 食パン耳, 馬鈴薯皮, ポテトチッ プ屑, ジャム製品ロス, 緑茶抽出かす, 豆腐かすな どの食品製造副産物を主体にして, 肥育豚用の飼 料を栄養設計し, 乳酸菌Lactobacillus plantarum A305 株を用いて FLF を調製したが，給与 豚の嗜好性は高く，市販配合飼料を与えた対照区 を上回る発育成績を示したことから，現在，食パ ン耳以外はコンポスト原料として堆肥化処理され ているこれらの製造副産物は, 発酵リキッド化法 により飼料利用が可能となり, 資源の有効活用之 排出サイド・畜産サイド双方の経済性向上に寄与 できる可能性が示唆された。

\section{謝辞}

本研究を実施するにあたり, 飼料の栄養設計に 関するご指導をいただいた独立行政法人農業・食 品産業技術総合研究機構畜産草地研究所機能性飼 料研究チーム, 川島知之チーム長に感謝申し上げ ます。また，給与試験に協力いただいた広島県立 西条農業高等学校実習農場, 久保秋人教諭, なら びに同校畜産科 2 学年養豚プロジェクト 9 名の生 徒さんに深く感謝申し上げます。

本研究は, 食協(株), (株)アンデルセンサービ ス, カルビー(株), アョ八夕(株), 宝積飲料(株), (株)カンサイ, (株)サ夕ケの 7 社が, 平成 16 年度 ひろしま産業創生研究補助事業 (リサイクル枠) により実施した。

\section{文献}

1）農林水産省 : 食料・農業・農村基本計画, 38, 2005.

2）配合飼料供給安定機構: 食品残さの飼料化 をめざして，113-137， 2006.
3）井尻 哲: 食品廃棄物の飼料化に打ける基 本視点, 地域資源活用食品加工総覧第 3 巻 共通編, 683-690, 農山漁村文化協会, 東 京, 2004 .

4）阿部 亮 - 吉田宣夫 - 今井明夫 - 山本英雄 編: 未利用有機物資源の飼料利用ハンド ブック，63-196，（株)サイエンスフォーラ 么, 東京, 2000.

5）佐伯真魚・川島知之: 食品廃棄物の飼料利 用 その 3 . 食品残さ飼料の栄養特性, 畜 産の研究，58，245-250， 2004.

6）入江正和・西村和彦: 豚の脂肪の性状に及 ぼす残飯給与と屠殺月齢, 蓄積部位の影 響，日本畜産学会報， 57，642-648， 1986.

7）淡路和則：リサイクル社会における養豚の 役割を考える，PIG JOURNAL，38，1014, 2001.

8）文部科学省・農林水産省・経済産業省・国 土交通省・環境省 : バイオマス・ニッポン 総合戦略骨子，1-6，2002.

9）蔡 義民: プロバイオティック乳酸菌を利 用した飼料調製加工技術，畜産の研究，59, 241-246, 2005.

10）広島県：資源循環広域システム構築事業 （有機性污泥等）報告書，41-49，広島県， 広島, 2004.

11）日本科学飼料協会: 飼料安全法関係通知集 第 1 版, 109-140, 2001.

12）山内慎也・角川幸治・松本英之 · 土屋義 信・井尻 哲: 食品残さの発酵リキッド飼 料化に用いる乳酸菌の特性評価, 日本養豚 学会誌，44，51-58， 2007.

13）農林水産省農林水産技術会議事務局編：日 本飼養標準・豚 (1998 年版), 13-21, 中央 畜産会，東京，1998.

14）(独)農業技術研究機構編: 日本標準飼料成 分表 (2001 年版), 94-121, 中央畜産会, 東 京, 2002.

15) Brooks, P.H., T.M. Ceary, D.T. Morgen and A. Campbell : New developments in liquid feeding, The Pig Journal Proceedings Section, 36, 43-64, 1996. 


\title{
Preparation of Fermented Liquid Feed Using By-products of Food Processing and the Growth Performance in Pigs
}

\author{
Satoru IJiri, Aki Nakayama*, Kimitaka Nakano**, Shinya Yamauchi***, \\ Koji Kakugawa*** and Yoshinobu Tsuchiya*** \\ Shokkyo Co., Ltd., 5-9 Matsukawa-chou, Minami-ku, \\ Hiroshima-shi, Hiroshima 732-0826, Japan \\ * Kansai Co., Ltd., 460 Ishiuchi, Itsukaichi-chou, Saeki-ku, \\ Hiroshima-shi, Hiroshima 731-5127, Japan \\ ** Hiroshima Prefectural Saijo Agricultural High School, 3-16-1 Kagamiyama, \\ Higashihiroshima-shi, Hiroshima 739-0046, Japan \\ *** Hiroshima Prefectural Technology Research Institute Food Technology \\ Research Center, 12-70 Hijiyamahon-machi, Minami-ku, \\ Hiroshima-shi, Hiroshima 732-0816, Japan
}

Fermented liquid feed (FLF), which was designed for growing-finishing pigs based on nutritional requirements, was prepared using by-products of food processing such as bread crusts, potato peelings, potato chip crumbs, jam residue, green-tea sullage, bean curd refuse, and other ingredients. FLF was fermented for $20 \mathrm{hr}$ at $33^{\circ} \mathrm{C}$ using Lactobacillus plantarum A305 as a starter. After fermentation, the concentration of lactic acid bacteria in the FLF reached $10^{9} \mathrm{cfu} / \mathrm{g}$ and the $\mathrm{pH}$ value of the FLF decreased to 4.2 .

A feeding experiment was carried out to examine the difference in growth effects between formula feed (FF) and FLF. In the experiment, 11 pigs were used. They were divided into two groups based on weight. A control group was fed FF and an experimental group was fed FLF, ad libitum for 16 days. The average daily weight gain (DG) for the control group and the experimental group was $965 \mathrm{~g} / \mathrm{d}$ and $1,207 \mathrm{~g} / \mathrm{d}$ respectively $(\mathrm{P}<0.05)$. The growth performance of pigs fed FLF increased in proportion to nutritional intake, and the feed conversion ratio calculated based on the total dry matter intake of the experimental group fed FLF (2.96) was superior to that of the control group fed FF (3.16) in the experiment.

Jpn. J. Swine Science, 44, $2: 31-39$

Key words : by-products of food, fermented liquid feed, growth performance, pig 